\title{
Relevance of sprinkler irrigation time of the day on alfalfa forage
}

production

Jose Cavero ${ }^{a,{ }^{*}}$, Jose M. Faci ${ }^{\mathrm{b}}$, Antonio Martínez-Cob ${ }^{\mathrm{a}, \mathrm{c}}$

a Departamento de Suelo y Agua, Estación Experimental de Aula Dei (CSIC),

Avda. Montañana 1005, 50059 Zaragoza, Spain.

${ }^{\mathrm{b}}$ Unidad de Suelos y Riegos (Unidad Asociada EEAD-CSIC), Centro de

Investigación y Tecnología Agroalimentaria (CITA-DGA), Avda. Montañana

930, 50059 Zaragoza, Spain.

${ }^{\mathrm{c}}$ Dr. A. Martínez-Cob passed away during this research.

${ }^{*}$ Corresponding author.

E-mail address: jcavero@eead.csic.es (J. Cavero)

\section{ABSTRACT}

Nighttime sprinkler irrigation usually results in lower water losses and higher irrigation uniformity compared with daytime sprinkler irrigation due to lower wind speed. However, daytime sprinkler irrigation modifies the microclimatic conditions within the crop canopy which could result in improved crop growth. We studied during three years the effect of daytime and nighttime irrigation on the yield, $\mathrm{N}$ content, $\mathrm{N}$ uptake, water use efficiency, microclimate and canopy temperature of an alfalfa (Medicago sativa L.) crop irrigated with a solid-set sprinkler system in a semiarid Mediterranean climate. Two irrigation treatments were tested: daytime irrigation and nighttime irrigation. The same irrigation amount was applied in both treatments (552 to $757 \mathrm{~mm}$ year ${ }^{-1}$ ). The water losses of daytime irrigation (10\%) tripled the water losses of nighttime 
1 irrigation (3\%). In one year, daytime irrigation decreased the mean Christiansen

2 coefficient of uniformity (CU) by $4 \%$ and the seasonal CU by $2 \%$. Microclimatic

3 and canopy temperature changes during sprinkler irrigation were higher for

4 daytime irrigation as compared to nighttime irrigation. Daytime irrigation slightly

5 reduced the soil water content of the surface layer $(0-0.3 \mathrm{~m})$. The actual

6 seasonal crop evapotranspiration was slightly higher (+3.7\%) in the daytime

7 irrigation treatment compared to the nighttime irrigation treatment only in one of

8 the years. The annual alfalfa forage yield (16 to $22 \mathrm{Mg} \mathrm{ha}^{-1}$ ), $\mathrm{N}$ content (3.16 to

$93.38 \%$ ), $\mathrm{N}$ uptake (514 to $740 \mathrm{~kg} \mathrm{ha}^{-1}$ ) and water use efficiency (17.7 to $25.9 \mathrm{~kg}$

$10 \mathrm{ha}^{-1} \mathrm{~mm}^{-1}$ ) were not affected by the irrigation time of the day. Although nighttime

11 sprinkler irrigation results in some water saving, daytime sprinkler irrigation of

12 alfalfa can be performed if necessary.

14 Keywords: Water losses

15 Irrigation uniformity

16 Semiarid

17 Microclimatic changes,

18 Water use efficiency

19 Abbreviations: CIR, crop irrigation requirement; CWSI, crop water stress index;

$20 \mathrm{CU}$, Christiansen coefficient of uniformity; ETo, reference evapotranspiration;

21 ETc, crop evapotranspiration; GMT, Greenwich Mean Time; WDEL, wind drift 22 and evaporation losses. 


\section{1- INTRODUCTION}

In order to reduce investments costs, sprinkler irrigation systems are usually designed to operate during daytime and nighttime hours. Irrigation efficiency depends on both water losses and uniformity of water distribution. For sprinkler irrigation systems these two factors are affected by the environmental conditions during the irrigation event, which are very different during daytime and nighttime irrigation events (Cavero et al., 2008; Playán et al., 2005).

In sprinkler irrigation wind is the main environmental factor affecting water losses (Playán et al., 2005) and irrigation uniformity (Dechmi et al., 2003; Kincaid et al., 1996; Seginer et al., 1991; Tarjuelo et al., 1999a). It is well known that wind speed is higher during daytime than during nighttime (Doorenbos and Pruitt, 1977). Consequently, higher water losses (Cavero et al., 2008; Playán et al., 2005) and lower irrigation uniformity (Cavero et al., 2008) are found during daytime irrigation compared to nighttime irrigation.

The irrigation water evaporated during the sprinkler irrigation changes the microclimate of the irrigated area during the irrigation event and some time (2-3 hours) after the irrigation event (Cavero et al., 2009; Playán et al., 2005; Robinson, 1970; Tolk et al., 1995; Urrego-Pereira et al., 2013a,b). These changes (decrease of VPD and temperature of the air) are more relevant during daytime irrigation and cause some physiological changes: a decrease of crop transpiration (Cavero et al., 2009; Martínez-Cob et al., 2008; McNaughton, 1981) and crop canopy temperature (Cavero et al., 2009; Saadia et al., 1996; Steiner et al., 1983; Tolk et al., 1995), and an increase of leaf water potential (Cavero et al., 2009; Howell et al., 1971). Moreover, during the daytime 
1 sprinkler irrigation events the net photosynthesis of crops can be affected

2 (Urrego-Pereira et al., 2013c).

Previous work with maize has shown that daytime sprinkler irrigation with a solid-set system in a Mediterranean climate decreased the grain yield by 5 to $13 \%$ compared to nighttime sprinkler irrigation (Cavero et al., 2008; Urrego-

6 Pereira et al., 2013b). This yield decrease was mainly caused by the lower

7 irrigation uniformity of daytime irrigation (Urrego-Pereira et al., 2013b) and by

8 the decrease of maize net photosynthesis during the daytime irrigation events

9 (Urrego-Pereira et al., 2013c). The reduction of net photosynthesis of maize

10 during sprinkler irrigation was related both with the high wettability of maize

11 leaves, which reduced the exchange of $\mathrm{CO}_{2}$, and with the reduction of canopy

12 and air temperature, which resulted in temperatures below the optimum for

13 photosynthesis of maize (Urrego-Pereira et al., 2013c). Thus, daytime sprinkler

14 irrigation with solid-set systems under similar climatic conditions to that study

15 site should be avoided for maize due to decreased yield. Mediterranean areas. It is rather different to maize in terms of sensitivity to water stress, crop height, leaf water wettability and optimal temperature for growth. Alfalfa for forage is considered to be less sensitive to water stress than maize due to its deep rooting system and because it does not have a

21 phenological stage very sensitive to water stress as maize (Sheaffer et al., 1988). Sánchez et al. $(2010 a, b)$ reported that irrigation uniformity of sprinkler irrigation was higher for alfalfa than for maize due to the lower plant height of alfalfa. They also found higher soil water recharge with sprinkler irrigation in alfalfa compared to maize. This could be related to the higher hydrophobicity of 
1 alfalfa leaves (Holder, 2012; Urrego-Pereira et al., 2013c). Urrego-Pereira et al.

2 (2013c) found that daytime sprinkler irrigation with a solid-set system at the same Mediterranean site did not affect net photosynthesis of alfalfa. The low wettability of alfalfa leaves prevented sprinkler irrigation water from interfering with the $\mathrm{CO}_{2}$ uptake and therefore did not decrease net photosynthesis.

Moreover, sprinkler irrigation did not decrease air and canopy temperature below the optimum range for photosynthesis of alfalfa.

There is no field data about how the sprinkler irrigation time of the day affects the alfalfa forage yield and quality. The main objective of this research was to study the effect of daytime versus nighttime irrigation on the forage yield and quality and water use efficiency of an alfalfa crop using a solid-set sprinkler irrigation system. We also studied the microclimatic and alfalfa canopy temperature changes due to daytime and nighttime sprinkler irrigation.

\section{2- MATERIALS AND METHODS}

\section{1- Experimental site}

The field experiment was carried out during three years (2012-2014) in a 2.34 ha field irrigated with solid-set sprinkler system, located at Zaragoza, Spain $\left(41^{\circ} 43^{\prime} \mathrm{N}, 0^{\circ} 48^{\prime} \mathrm{W}, 225 \mathrm{~m}\right.$ altitude). The climate is Mediterranean semiarid with long-term annual averages of $14.1^{\circ} \mathrm{C}$ for air temperature, $298 \mathrm{~mm}$ for precipitation, and $1243 \mathrm{~mm}$ for grass reference crop evapotranspiration (ETo). The soil is clay loam and classified as Typic Xerofluvent (Table 1).

\section{2- Experimental layout}

The experimental field was divided in twelve irrigation sectors which were irrigated independently by four sprinklers each (Fig. 1). The borders of the field 
1 were irrigated independently of the main twelve irrigation sectors. The sprinkler

2 spacing was a square of $18 \mathrm{~m} \times 18 \mathrm{~m}$. The impact sprinkler and nozzles were

3 manufactured in brass (RC-130, Riegos Costa, Lérida, Spain). The sprinkler

4 has a vertical throw angle of $25^{\circ}$, the nozzle diameters were $4.4 \mathrm{~mm}$ (main) and

$52.4 \mathrm{~mm}$ (auxiliary), and the nozzle height was $2.50 \mathrm{~m}$ above the soil surface.

6 The nozzle operating pressure was kept constant at $0.3 \mathrm{MPa}$ with a hydraulic

7 pressure control valve. Sprinkler application rate was $5 \mathrm{~mm} \mathrm{~h}^{-1}$ and the wetted

8 radius was $15 \mathrm{~m}$. The irrigation volume was measured with an electromagnetic

9 flow meter (Promag 50, Endress+Hauser, Reinach, Switzerland) with $\pm 0.5 \%$

10 measurement error.

11 Alfalfa cv. Aragón was planted on 20 Sept. 2011 at a planting rate of 33

$12 \mathrm{~kg} / \mathrm{ha}$. The previous crop was wheat (Triticum aestivum L.). Several sprinkler

13 irrigation events of 5 to $10 \mathrm{~mm}$ were applied on Sept.-Oct. 2011 after planting to

14 promote the emergence of alfalfa. A total of 14 irrigation events and $105 \mathrm{~mm}$

15 were applied. Fertilization consisted of $200 \mathrm{~kg} \mathrm{ha}^{-1} \mathrm{P}_{2} \mathrm{O}_{5}$, and $200 \mathrm{~kg} \mathrm{ha}^{-1} \mathrm{~K}_{2} \mathrm{O}$

16 applied on March every year. Pests control was carried out following the best

17 management practices provided by the Pest Control Centre of Aragon. No

18 herbicide was applied during the experiment.

\section{2-3- Irrigation treatments}

The meteorological data recorded at a weather station over grass located

$211 \mathrm{~km}$ southwest from the experimental field were used to compute the reference

$22 \mathrm{ET}_{0}$ using the FAO Penman-Monteith method (Allen et al., 1998). Crop coefficients $\left(K_{c}\right)$ were calculated as a function of thermal time considering the duration of the four phases proposed by Allen et al. (1998) and the Kc initial,

25 midterm and final values according to the meteorological conditions of the 
1 location of the experiment (Martínez-Cob and García-Vera, 2004). The use of

2 thermal time to calculate the Kc for alfalfa has been recommended by Sammis

3 et al. (1985). Thermal time was computed as the cumulative daily difference

4 between daily mean air temperature and a basal air temperature of $6{ }^{\circ} \mathrm{C}$

5 (Breazele et al., 1999; Sharrat et al., 1989) and considering a thermal time of

$6360 \stackrel{\circ}{\circ}$ day for the first harvest and $500{ }^{\circ}$ Cday for the rest of the harvests. Daily

7 crop evapotranspiration of alfalfa $\left(E T_{c}\right)$ was then obtained as the $E T_{0}$ multiplied 8 by the $\mathrm{K}_{\mathrm{c}}$.

The crop irrigation requirements (CIR) were calculated weekly as the

10 difference between $\mathrm{ET}_{\mathrm{c}}$ and the effective precipitation, which was estimated as

$1175 \%$ of precipitation (Dastane, 1978). The initial soil water content above the

12 wilting point at the $0-1.6 \mathrm{~m}$ depth was considered as available for the crop and

13 subtracted from the CIR at the beginning of the crop season. The irrigation

14 amount applied to the crop was equal to the CIR. Two irrigation treatments were

15 tested: daytime and nighttime irrigation. Daytime irrigation generally started at

161000 Greenwich Mean Time (GMT) while nighttime irrigation started at 2200

17 GMT of the same day. The same irrigation amount was applied to both

18 treatments. The weekly irrigation amount was generally applied in two irrigation

19 events that lasted 4 to 6 hours depending on CIR. The experimental plot was

20 the area surrounded by the four sprinklers of each irrigation sector (Figure 1)

21 and has an area of $324 \mathrm{~m}^{2}$. The area outside was not considered because it

22 received water from two different irrigation sectors. The experimental design

23 was randomized with six replicates per treatment. The experimental plots

24 irrigated during daytime in 2012 (Figure 1) were irrigated during nighttime in

252013 , and were irrigated during daytime in 2014. In 2014 the soil water content 
1 measured at the beginning of the season indicated that the plots that had been

2 daytime irrigated in 2013 had a lower soil water content $(-12 \mathrm{~mm})$ compared to

3 those nighttime irrigated in 2013. Thus, an irrigation of $12 \mathrm{~mm}$ was applied in

4 those plots on 24 March 2014 in order to have the same initial soil water content

5 in the two irrigation treatments.

6 The irrigation efficiency was evaluated determining the wind drift and

7 evaporation losses (WDEL) (Frost and Schwalen, 1955) and the uniformity of

8 application through the coefficient of uniformity (CU) (Christiansen, 1942). For

9 this, one grid of catch cans was placed at one experimental plot irrigated during

10 daytime and another grid of catch cans was placed at one experimental plot

11 irrigated during nighttime (Fig. 1). Each grid had 25 catch cans, which were

12 arranged in five rows and five columns with a distance of $3.6 \mathrm{~m}$ between catch

13 cans. The catch cans were made of plastic, with an opening diameter of $0.18 \mathrm{~m}$

14 and a maximum capacity of $45 \mathrm{~L} \mathrm{~m}^{-2}$. The catch cans were marked in $\mathrm{mm}$ with a

15 resolution of $1 \mathrm{~mm}$ in order to read directly the collected irrigation depth just

16 after each irrigation event. The catch cans were placed above the crop canopy

17 at $1 \mathrm{~m}$ above the soil surface.

18 The WDEL were calculated as:

19 WDEL $=100\left(\frac{\mathrm{I}_{\mathrm{fm}}-\mathrm{I}_{\mathrm{cc}}}{\mathrm{I}_{\mathrm{fm}}}\right)$

20 where $I_{f m}(\mathrm{~mm})$ is the applied irrigation depth measured with the flow meter; and

$21 \mathrm{I}_{\mathrm{cc}}(\mathrm{mm})$ is the mean value of collected water depth in the catch cans.

22 The CU was computed using the methodology described by Christiansen

23 (1942) as:

$24 \quad \mathrm{CU}=100\left[1-\frac{\sum\left(\mathrm{x}_{\mathrm{i}}-\mathrm{I}_{\mathrm{CC}}\right)}{\mathrm{I}_{\mathrm{CC}} \mathrm{n}}\right]$ 
1 where $x_{i}-I_{c c}$ is the deviation of the individual observations from the mean

2 value of collected water depth in the catch cans, and $\mathrm{n}$ is the number of catch

3 cans of the grid.

\section{4- Soil water content}

One soil core of $0.05 \mathrm{~m}$ diameter was taken from the centre of each experimental plot on September 2011 to a depth of $1.8 \mathrm{~m}$ at $0.30 \mathrm{~m}$ intervals and the gravimetric soil water content was determined.

Two $1.80 \mathrm{~m}$ plastic tubes were installed in the soil of each experimental plot on March 2012. One was located centred in the $18 \mathrm{~m} \times 18 \mathrm{~m}$ square of the plot and the other at $4 \mathrm{~m}$ of one corner (Fig. 1). The gravimetric soil water content was determined at $0.3 \mathrm{~m}$ intervals in the soil cores taken for the installation of the plastic tubes. A capacitance sensor (Diviner 2000, Sentek Pty Ltd, Stepney, Australia) of $1.60 \mathrm{~m}$ length was used to take measurements every $0.10 \mathrm{~m}$. In order to calibrate the capacitance probe, five $1.80 \mathrm{~m}$ plastic tubes were located close to the main plots. On 20 May 2012 the capacitance probe was used to get readings of the five tubes every $0.10 \mathrm{~m}$. Immediately undisturbed soil samples were taken to determine the volumetric soil water content. A regression equation was derived from the capacitance readings and the volumetric soil water content. Measurements of soil water content with the capacitance probe were made with a two-three week frequency during the crop season. The average values of the soil water content measured in the two tubes installed in each experimental plot were used for statistical analysis.

\section{5- Microclimatic and crop canopy temperature changes}

Two automatic weather stations were installed just at the border of two experimental plots (one daytime irrigated and one nighttime irrigated) in order 
1 not to interfere with alfalfa harvesting operations (Fig. 1). These weather

2 stations were used to record the temperature and VPD of the air and the crop

3 canopy temperature during the crop season so comparisons could be made

4 between the plot that was irrigated and the plot that was not irrigated at that 5 time.

6 Two temperature and relative humidity probes (HMP45C, Vaisala,

7 Helsinki, Finland) were installed at each weather station at two heights: a) $1.0 \mathrm{~m}$

8 above the soil surface, and b) $2.0 \mathrm{~m}$ above the soil surface. Each probe was

9 installed inside a shield URS1 (Campbell Scientific, Logan, USA) which

10 protected it from irrigation water. The accuracy of the probes was $\pm 0.3^{\circ} \mathrm{C}$ for

11 temperature and $\pm 3 \%$ for relative humidity. The maximum crop canopy height

12 was $0.8 \mathrm{~m}$. The air temperature and relative humidity were measured every $10 \mathrm{~s}$

13 and the 5-min mean values were recorded in a datalogger (CR1000, Campbell

14 Scientific Inc, Logan, UT). The VPD was calculated from the air temperature

15 and relative humidity data (Allen et al., 1998). An infrared thermometer (IR120,

16 Apogee Instruments Inc., Roseville, CA, USA) with an accuracy of $\pm 0.2^{\circ} \mathrm{C}$ was

17 installed in each of the automatic weather stations to measure the crop canopy

18 temperature. The infrared thermometer was located at $2.0 \mathrm{~m}$ above the soil

19 surface with an angle of $45 \stackrel{\circ}{ }$ and was oriented towards the south measuring

20 inside the experimental plot. Canopy temperature measurements were taken at

$2110 \mathrm{~s}$ intervals and average values every 5 min were recorded in the

22 dataloggers.

In one of the weather stations, a pyranometer (LP02, Hukseflux, Delft,

24 The Netherlands) was installed at $2.0 \mathrm{~m}$ above the soil surface to measure solar 
1 radiation at $10 \mathrm{~s}$ intervals and average values every $5 \mathrm{~min}$, that were recorded

2 in the datalogger.

The crop water stress index (CWSI) was calculated daily for the two

4 irrigation treatments with the data measured in the two experimental plots: air

5 temperature and VPD data measured at $2 \mathrm{~m}$, and canopy temperature. CWSI

6 was calculated for those days that the experiment was not irrigated and

7 considering for each alfalfa harvest cycle that the thermal time was higher than

8 a third of the total to ensure that the alfalfa canopy was covering the soil

9 surface. Cloudy days were excluded from CWSI calculation. The average data

10 measured from 12:00 GMT to 14:00 GMT was used to calculate the daily CWSI.

11 The lower and upper baselines for the relationship between VPD and canopy

12 minus air temperature proposed by Abdul-Jabbar et al. (1985) were used to

13 calculate the CWSI.

\section{6- Alfalfa forage yield and $\mathbf{N}$ content}

Six alfalfa harvests were performed each year. A commercial cutting machine 3-m wide was used to cut the alfalfa at $7 \mathrm{~cm}$ above the soil surface.

One day after cutting, the alfalfa forage in two samples (2-m x 6-m) was taken at each experimental plot. The alfalfa forage of each sample was weighted and a subsample was taken and dried at $60^{\circ} \mathrm{C}$ to determine the moisture content of the alfalfa forage. Once dried, the subsample was grinded and analysed to

21 determine the $\mathrm{N}$ content by combustion (TruSpec CN, LECO, St. Joseph, MI, 22 USA). The forage yield and $\mathrm{N}$ content average values of the two samples of each experimental plot were used for statistical analysis. The rest of the alfalfa was left in the field for sun drying after cutting during three days and then removed and transported to a dehydration plant. All tillage operations were 
1 made with commercial equipment. The $\mathrm{N}$ uptake was obtained from the forage

2 yield and $\mathrm{N}$ content.

3

\section{7- Water use efficiency}

The water balance was used to calculate the actual alfalfa ET at each plot during each season. Irrigation applied, rainfall and the change in soil water content between the closest measurement date to the start of alfalfa growth at winter time (late February) and to the last harvest cycle (October) were used. Soil water content data suggested that water did not leach below the measurement depth $(1.60 \mathrm{~m})$. The water use efficiency was calculated for each plot as the ratio between the seasonal alfalfa forage yield and the seasonal actual ET of alfalfa.

\section{8- Statistical analysis}

The effect of irrigation time on soil water content, alfalfa forage yield, $\mathrm{N}$ content, $\mathrm{N}$ uptake, seasonal alfalfa actual ET and water use efficiency was analyzed with ANOVA at a level of significance of $P=0.05$.

For each irrigation event the air temperature and VPD and the crop canopy temperatures of the experimental plot that was irrigated were compared with that of the experimental plot that was not irrigated. The irrigation events considered were those when thermal time was more than a third of total for each alfalfa harvest cycle. Comparison was made of the average values for the periods: 1 hour before the irrigation event, during the irrigation event, and 1 and 2 hours after the irrigation event. Comparison was made using a paired t-test and a level of significance of $P=0.05$. 
For each alfalfa harvest cycle the daily values of the CWSI calculated for

2 the two irrigation treatments were compared using a paired t-test and a level of 3 significance of $P=0.05$.

4

\section{3- RESULTS}

\section{1- Irrigation applied and characteristics of irrigation events}

The soil available water at planting was $41 \mathrm{~mm}$ in 2012, $72 \mathrm{~mm}$ in 2013, and $84 \mathrm{~mm}$ in 2014. The seasonal rainfall was $215 \mathrm{~mm}$ in 2012, $271 \mathrm{~mm}$ in 2013, and $178 \mathrm{~mm}$ in 2014 (Fig. 2). The calculated ETc ranged from $832 \mathrm{~mm}$ to $941 \mathrm{~mm}$ and the CIR ranged from $556 \mathrm{~mm}$ to $746 \mathrm{~mm}$ (Table 2). The seasonal irrigation amount applied was close to the CIR with a difference of only 1 to 11 $\mathrm{mm}$, values that represent less than $1.5 \%$ of the CIR (Table 2; Fig. 2). In general, the weekly applied irrigation amount was close to the CIR (Fig. 2), but some discrepancies occurred during the season, mostly due to rainfall.

The average wind speed during the daytime irrigation events was higher than during the nighttime irrigation events all years and all alfalfa harvest cycles (Table 3). The average daytime wind speed during each alfalfa harvest cycle ranged from 1.5 to $4.4 \mathrm{~m} \mathrm{~s}^{-1}$, and on $70 \%$ of the alfalfa harvest cycles the wind speed was higher than the threshold value of $2.1 \mathrm{~m} \mathrm{~s}^{-1}$ reported by Faci and Bercero (1991) for adequate irrigation uniformity in our region. However, for the nighttime irrigation events, the average wind speed was only higher than the indicated threshold in one alfalfa harvest cycle period.

The average WDEL of the daytime irrigation events for each alfalfa harvest cycle period ranged from 3.0 to $19.6 \%$, while the average WDEL of the nighttime irrigation events for each alfalfa harvest cycle period ranged from 0 to 
$16.5 \%$. In general, greater losses of water occurred with higher wind speeds

2 during daytime irrigations, but the relationship was not so clear for the nighttime

3 irrigations. The annual average of WDEL was around $10 \%$ for the daytime

4 irrigation events, while it was between 1 and $4 \%$ for the nighttime irrigation

5 events (Table 3). The seasonal value of WDEL ranged from 59 to $71 \mathrm{~mm}$ for the

6 daytime irrigation treatment while it ranged from 7 to $29 \mathrm{~mm}$ for the nighttime

7 irrigation treatment.

The annual average CU was similar for daytime and nighttime irrigation

9 events in 2012 and 2013 (Table 3). When considering the seasonal irrigation

10 amounts collected at each catch can, the seasonal CU was also the same for

11 both daytime and nighttime irrigation in 2012 and 2013. However, in 2014 the

12 average $\mathrm{CU}$ during daytime irrigation events was lower than during nighttime

13 irrigations (Table 3) and, similarly, the seasonal CU was lower for daytime

14 irrigation (92\%) compared to nighttime irrigation (94\%). The lower CU for

15 daytime irrigation events in 2014 was related to the higher wind speed.

16 Considering the average $\mathrm{CU}$ at each alfalfa harvest cycle there were only four

17 harvest cycles where the difference of CU between the irrigation treatments was

18 higher than 5\% (one in 2012 and the others in 2014) and in all of them the CU

19 was higher in the nighttime irrigation treatment. The higher difference between

20 the daytime and nighttime irrigation events was found in harvest cycle 4 of

212014 , when the CU of daytime irrigation events was only $76 \%$ but the $\mathrm{CU}$ of

22 nighttime irrigation events was $88 \%$. This high difference was due to the high

23 wind speed at the daytime irrigation events $\left(4.40 \mathrm{~m} \mathrm{~s}^{-1}\right)$. 


\section{2- Soil water content}

The soil water content was close to the wilting point in the $0-0.6 \mathrm{~m}$ depth before starting the irrigation the first year of the experiment (2012) (Fig. 3). However, it was above the wilting point at deeper soil layers. During the first year of the experiment, after the irrigation started the soil water content in the 0 $0.3 \mathrm{~m}$ soil layer was higher in the daytime irrigation treatment compared to the nighttime irrigation treatment in two out of twelve dates (Fig. 3). However, in one date the soil water content in the $0.3-0.6 \mathrm{~m}$ soil layer was higher in the nighttime irrigation treatment compared to the daytime irrigated treatment. At deeper soil depths, there were not differences of soil water content between the irrigation treatments.

During the second year of the experiment (2013), after the irrigation started the soil water content in the $0-0.3 \mathrm{~m}$ soil layer was higher in the nighttime irrigation treatment compared to the daytime irrigation treatment in six out of ten dates (Fig. 3). At deeper soil depths, there were not differences of soil water content between the irrigation treatments.

As explained in the Materials and Methods, before starting the irrigation treatments in 2014 the soil water content measured at the plots that had been daytime irrigated in 2013 (nighttime irrigated in 2014) had a lower soil water content compared to those nighttime irrigated in 2013 (daytime irrigated in 2014) (Fig. 3). Thus, an irrigation was applied in those plots on 24 March 2014 in order to have the same initial soil water content before starting the irrigation treatments. During the third year of the experiment (2014), after the irrigation started the soil water content in the $0-0.3 \mathrm{~m}$ soil layer was higher in the nighttime irrigation treatment compared to the daytime irrigation treatment in 
1 three out of ten dates (Fig. 3). Moreover, in one date the soil water content in

2 the 0.3-0.6 $\mathrm{m}$ soil layer was also higher in the nighttime irrigation treatment

3 compared to the daytime irrigation treatment. At deeper soil depths, there were

4 no differences of soil water content between the irrigation treatments.

\section{3- Microclimatic and crop canopy temperature changes}

During the daytime irrigation events the air temperature above the crop canopy, at $1 \mathrm{~m}$ and $2 \mathrm{~m}$ above the soil surface, significantly decreased (Table 4). The decrease of air temperature due to the irrigation was slightly higher as the measurement height was closer to the soil surface and ranged from 0.9 to $1.3^{\circ} \mathrm{C}$ at $1 \mathrm{~m}$ and from 0.4 to $1.3^{\circ} \mathrm{C}$ at $2 \mathrm{~m}$. During the hour following the irrigation events the decrease of air temperature was significant at $1 \mathrm{~m}$ all years but only one year at $2 \mathrm{~m}$, and its magnitude $\left(0.3\right.$ to $\left.0.8^{\circ} \mathrm{C}\right)$ was lower than during the irrigation events (Table 4). The decrease of air temperature almost disappeared $2 \mathrm{~h}$ after the irrigation event finished. During the nighttime irrigation events the air temperature significantly decreased in two years but the decrease was lower than in the daytime irrigations, ranging from 0.3 to $0.9^{\circ} \mathrm{C}$ (Table 5). This decrease lasted for $2 \mathrm{~h}$ after the irrigation event finished.

During the daytime irrigation events the air VPD at the different measurement heights significantly decreased and its magnitude ranged from 0.19 to $0.33 \mathrm{kPa}$ (Table 4). The decrease of air VPD due to the irrigation was slightly higher as the measurement height was closer to the soil surface in 2014. During the hour following the irrigation events the decrease of air VPD was significant but its magnitude was lower than during the irrigation event. The decrease of air temperature disappeared $2 \mathrm{~h}$ after the irrigation event finished. 
1 During the nighttime irrigation events, the air VPD at the different measurement

2 heights significantly decreased but the decrease was much lower than in the

3 daytime irrigations, ranging from 0.04 to $0.11 \mathrm{kPa}$ (Table 5). In general, this

4 decrease lasted for $2 \mathrm{~h}$ after the irrigation event finished.

Alfalfa canopy temperature was significantly reduced during the daytime

6 sprinkler irrigation events (Table 4). The mean reduction ranged from $0.7^{\circ} \mathrm{C}$

7 (2013) to $2.1^{\circ} \mathrm{C}(2014)$. Once the daytime irrigation finished the decrease of

8 alfalfa canopy temperature disappeared (except in 2014 one hour after the

9 irrigation). However, during the nighttime irrigation events the alfalfa canopy

10 temperature was significantly reduced by the irrigation only in one year but it

11 was decreased after the irrigation finished all years (Table 5).

12 In the first alfalfa harvest cycle, that generally corresponded to the period

13 of March-mid April, the average daily value of CWSI was high and in two years

14 (2012 and 2014) was slightly higher in the nighttime irrigated treatment while in

152013 was clearly higher in the daytime irrigated treatment (Table 6). The

16 average daily value of CWSI in the harvest cycles 2 (mid April-May), 3 (June)

17 and 4 (July) was not affected by the irrigation treatment in 2012 and 2014 but it

18 was higher in the daytime irrigated treatment in 2013 . The average daily value

19 of CWSI in the harvest cycles 5 (August) and 6 (September-mid October) was

20 not affected by the irrigation treatment in 2013 and 2014 but it was slightly

21 higher in the nighttime irrigated treatment in 2012.

\section{4- Alfalfa forage yield and $\mathrm{N}$ content}

The annual alfalfa forage yield was not affected by the irrigation time of

the day in any of the three years of the experiment (Table 7). When analysing the yield at each harvest cycle only in one out of 18 harvests the irrigation 
1 treatment affected the alfalfa forage yield. It was in harvest 4 on 2014, when the

2 daytime irrigation reduced by $10 \%$ the alfalfa yield compared to the nighttime

3 irrigation. As explained before, at this harvest the $\mathrm{CU}$ of the daytime irrigation

4 treatment was much lower than the $\mathrm{CU}$ of the nighttime irrigation treatment. In any case, this difference found in one harvest did not result in differences in the

6 annual alfalfa forage yield between the two irrigation treatments.

The annual yield weighted average $\mathrm{N}$ content of the alfalfa forage was not affected by the irrigation time of the day in any of the three years of the experiment (Table 8). The $\mathrm{N}$ content was higher than 3\% (considered as good) in $88 \%$ of the alfalfa harvest cycles and the annual yield weighted average was,

11 generally, higher than $3.2 \%$, which is considered as premium (Putnam et al., 12 2008). Only in one out of 18 alfalfa harvest cycles the irrigation treatment

13 affected the alfalfa forage $\mathrm{N}$ content. It was in harvest 4 on 2014, when the nighttime irrigation reduced the $\mathrm{N}$ content of alfalfa forage compared to the daytime irrigation. The $\mathrm{N}$ uptake of the alfalfa forage was not affected by the irrigation time of the day in any of the three years of the experiment and in any of the alfalfa harvest cycles.

\section{5- Water use efficiency}

In one of the years the seasonal actual evapotranspiration calculated

with the water balance was slightly higher in the daytime irrigation treatment compared to the nighttime irrigation treatment (Table 9). However, the water use efficiency was not affected by the irrigation treatment in any year (Table 9). 


\section{4- DISCUSSION}

The microclimatic changes caused by the sprinkler irrigation (decreased air temperature and VPD) were more pronounced during daytime irrigation events as found by others (Cavero et el., 2009; Liu and Kang, 2006). This was related with the higher WDEL during daytime irrigation. The microclimatic changes induced plant physiological responses such as the decrease in canopy temperature (Cavero et al., 2009; Liu and Kang, 2006; Saadia et al., 1996; Steiner et al., 1983; Tolk et al., 1995). The decrease in canopy temperature of alfalfa during the daytime irrigation events found in our study was lower to that found by Cavero et al. (2009) in the same plot for maize. This could be related to the fact that maize leaves are wettable while alfalfa leaves are non wettable (Urrego-Pereira et al., 2013c). Thus, water drops do not cover the alfalfa leaves during the irrigation, differently from maize, which could result in a lower cooling of alfalfa leaves.

The alfalfa forage yield obtained, $16 \mathrm{Mg} \mathrm{ha}^{-1}$ in the first year and 20-22 $\mathrm{Mg} \mathrm{ha}^{-1}$ in the following years, is in the high range of reported from semiarid areas (Grimes et al., 1992; Isla and Aragüés, 2009; Lindenmayer et al., 2011; Lloveras et al., 2008; Sheaffer et al., 1988; Smeal et al., 1992). The irrigation time of the day did not affect the seasonal forage yield and its $\mathrm{N}$ content in any of the three experimental years. This is different from the $5-13 \%$ reduction of maize yield found with daytime sprinkler irrigation compared to nighttime sprinkler irrigation at the same plots (Cavero et al., 2008; Urrego-Pereira et al., 2013b). The different response of alfalfa to sprinkler irrigation time of the day compared to maize is due to several facts. 
First, the average WDEL were lower in alfalfa (3\% for nighttime irrigation

2 to $10 \%$ for daytime irrigation) as compared to maize ( $8 \%$ for nighttime irrigation

3 and to $20 \%$ for daytime irrigation) (Cavero et al., 2008; Stambouli et al., 2013;

4 Urrego-Pereira et al., 2013b), which resulted in more water available for the

5 alfalfa crop. Moreover, the difference of WDEL between the daytime and

6 nighttime irrigation was also lower for alfalfa (7\%) than for maize (14\%). The

7 lower WDEL for alfalfa compared to maize has also been reported by Sánchez

8 et al. (2010a), who found that this resulted in more soil water in alfalfa after

9 sprinkler irrigation.

Second, in alfalfa the average and seasonal irrigation CU was similar

11 between the daytime and nighttime irrigation in two years and only was reduced

12 with daytime irrigation in one year. This is similar to what was found by

13 Stambouli (2012) in alfalfa, but different from what was found for maize, where

14 CU was lower with daytime irrigation in three out of four years (Cavero et al., 2008; Urrego-Pereira et al., 2013b). Besides, the average CU for alfalfa (85$89 \%$ ) was higher than for maize (75 to $84 \%$ ), and higher than $85 \%$, that is considered as slightly affecting yield (López-Mata et al., 2010; Tarjuelo et al., 1999b; Urrego-Pereira et al., 2013b). Sánchez et al. (2010a) also found higher CU for sprinkler irrigated alfalfa compared to sprinkler irrigated maize, which was due to the lower plant height of alfalfa that decreased the water interception

21 plane and allowed a better overlap of water emitted by the sprinklers (Sánchez et al., 2010b). In this sense it is interesting to notice that the only harvest cycle (one out of eighteen) when irrigation time of the day affected the alfalfa forage yield was the one when the average of daytime irrigation CU was $76 \%$ while the average of nighttime irrigation CU was $88 \%$. The relevance of the reduction of 
$1 \mathrm{CU}$ in the yield reduction of some crops has been studied by experimental and

2 simulation work (Bruckler et al., 2000; Mantovani et al., 1995; Salmeron et al.,

3 2012; Stern and Bresler, 1983). Thus, the maize yield reduction of 3 to $8 \%$ with

4 a decrease of CU from $88 \%$ to $76 \%$ reported (Salmeron et al., 2012; Stern and

5 Bresler, 1983) is close to the $10 \%$ alfalfa yield reduction found in our work at

6 that harvest cycle.

$7 \quad$ Third, a previous study at the same location found that daytime sprinkler

8 irrigation did not affect the net photosynthesis of alfalfa while it reduced the net

9 photosynthesis of maize (Urrego-Pereira et al., 2013c). This result agrees with

10 the similar forage alfalfa yield found in our work with daytime and nighttime

11 sprinkler irrigation and with the reduction of maize grain yield with daytime

12 sprinkler irrigation found in the above mentioned previous studies (Cavero et al.,

13 2008; Urrego-Pereira et al., 2013b).

Finally, although daytime sprinkler irrigation decreased the soil water content in the surface soil layer on some dates and increased the CWSI in the summer alfalfa harvest cycles in one of the years, its deep rooting system and moderate sensitivity to waters stress (Sheaffer et al., 1988) could also explain that the alfalfa forage yield was not affected by the irrigation time of the day. in the daytime irrigation treatment compared to the nighttime irrigation treatment

21 only in one of the years, probably due to the higher difference of the WDEL this year between the two irrigation treatments $(11 \%$ for daytime and $1 \%$ for nighttime). Although nighttime irrigation could result in some water saving, the similar alfalfa forage yield, $\mathrm{N}$ content, and water use efficiency found in this 
1 work indicates that daytime sprinkler irrigation of alfalfa can be performed if

2 necessary.

3

\section{5- CONCLUSIONS}

In a similar previous work with maize at the same site we had found that

6 daytime sprinkler irrigation decreased maize yield as compared to nighttime

7 sprinkler irrigation. However, this work has shown that the alfalfa forage yield, $\mathrm{N}$

8 content, $\mathrm{N}$ uptake and water use efficiency were not affected by the sprinkler

9 irrigation time of the day (daytime versus nighttime). This lack of influence of

10 sprinkler irrigation time of the day on the alfalfa crop was related to the low

11 sprinkler water losses (10\% for daytime and $3 \%$ for nighttime), the slight effect

12 of irrigation time of the day on the uniformity of irrigation, the null effect of

13 daytime sprinkler irrigation on photosynthesis found in a previous work, and the

14 moderate sensitivity of alfalfa to water stress.

For those farms that grow alfalfa and maize, when daytime sprinkler

16 irrigation is necessary due to constraints of the irrigation system, alfalfa should

17 be the crop daytime irrigated. Given that the effect of sprinkler irrigation time of

18 the day on crop production depends on crop species, further studies are

19 needed for other crops. 


\section{6- ACKNOWLEDGEMENTS}

2 This work was supported by the project AGL2010-21681-C03-01 (Ministerio de

3 Economía y Competitividad) of Spanish Government. We thank M. Izquierdo, J.

4 Gaudó, M. Guillen, M.A. Millán and P. Paniagua for the technical assistance in

5 the field and laboratory.

7 7- REFERENCES

8 Abdul-Jabbar, A.S., Lugg, D.G., Sammis, T.W., Gay, L.W., 1985. Relationships

9 between crop water stress index and alfalfa yield and evapotranspiration.

10 Trans. ASAE 28, 454-461.

11 Allen, R.G., Pereira, L.S., Raes, D., Smith, M., 1998. Crop evapotranspiration:

12 Guidelines for computing crop water requirements. Irrig. and Drain. Paper

13 56. FAO, Rome.

14 Breazeale, D., Kettle, R., Munk, G., 1999. Using growing degree days for alfalfa production. Fact Sheet 99-7. University of Reno, Nevada.

16 Bruckler, L., Lafolie, F., Ruy, S., Granier, J., Baudequin, D., 2000. Modeling the agricultural and environmental consequences of non-uniform irrigation on a corn crop. 1. Water balance and yield. Agronomie 20, 609-624.

19 Cavero, J., Jiménez, L., Puig, M., Faci, J.M., Martínez-Cob, A., 2008. Maize growth and yield under daytime and nighttime solid-set sprinkler irrigation. Agron. J. 100, 1573-1579. changes maize canopy microclimate and crop water status, transpiration, 24 and temperature. Agron. J. 101, 854-864. 
1 Christiansen, J.E., 1942. Irrigation by sprinkling. Agric. Exp. Stn. Bull. 670. Univ.

2 of California, Berkeley.

3 Dastane, N.G., 1978. Effective rainfall in irrigated agriculture. Irrig. and Drain. Paper 25. FAO, Rome.

5 Dechmi, F., Playan, E., Cavero, J., Faci, J.M., Martínez-Cob, A., 2003. Wind

6 effects on solid-set sprinkler irrigation depth and yield of maize (Zea mays).

$7 \quad$ Irrig. Sci 22, 67-77.

8 Doorenbos, J., Pruitt, W.O., 1977. Crop water requirements. Irrigation and Drainage Paper 24. FAO, Rome.

10 Faci, J.M., Bercero, A., 1991. Efecto del viento en la uniformidad y en las

11 pérdidas por evaporación y arrastre en el riego por aspersión. Inv. Agr.:

12 Prod. Prot. Veg. 6, 97-117.

13 Frost, K.R., Schwalen, H.C., 1955. Sprinkler evaporation losses. Agric. Eng. 36, $14 \quad 526-528$.

15 Grimes, D.W., Wiley, P.L., Sheesley, W.R., 1992. Alfalfa yield and plant water 16 relations with variable irrigation. Crop Sci. 32, 1381-1387.

17 Holder, C.D., 2012. The relationship between leaf hydrophobicity, water droplet retention, and leaf angle of common species in a semi-arid region of the western United States. Agric. Forest Meteo. 152, 11-16.

Howell, T.A., Hiler, E.A., van Bavel, C.H.M., 1971. Crop response to mist.

Trans. ASAE 14, 906-910.

Isla, R., Aragües, R., 2009. Response of alfalfa (Medicago sativa L.) to diurnal and nocturnal saline sprinkler irrigations. I: total dry matter and hay quality. Irrig. Sci. 27, 497-505. 
1 Kincaid, D.C., Solomon, K.H., Oliphant, J.C., 1996. Drop size distributions for

2 irrigation sprinklers. Trans. ASAE 39, 839-845.

3 Lindenmayer, R.B, Hansen, N.C., Brummer, J., Pritchett, J.G., 2011. Deficit irrigation of alfalfa for water-savings in the Great Plains and Intermountain West: a review and analysis of the literature. Agron. J. 103, 45-50.

6 Liu, H.J., Kang, Y., 2006. Effect of sprinkler irrigation on microclimate in the 
1 Playán, E., Salvador, R., Faci, J.M., Zapata, N., Martínez-Cob, A., Sanchez, I., 2 2005. Day and night wind drift and evaporation losses in sprinkler solid-sets 3 and moving laterals. Agric. Water Manage. 76, 139-159.

4 Putnam, D.H., Robinson, P., DePeters, E., 2008. Forage quality and testing, in: Summers, C.G., Putnam, D.H. (Eds.), Irrigated alfalfa management for Mediterranean and desert zones, Chapter 16, pp. 25. Oakland, Univ. of California. Agricultural and Natural resources publication $\mathrm{n}-8302$.

Robinson, F.E., 1970. Modifying an arid microclimate with sprinklers. Agric. Eng. 51, 465.

Saadia, R., Huber, L., Lacroix, B., 1996. Modification du microclimat d'un couvert de maïs au moyen de l'irrigation par aspersion en vue de la gestion des stress thermiques des organes reproducteurs. Agronomie 16, 465-477.

Salmeron, M., Urrego, Y.F., Isla, R., Cavero, J., 2012. Effect of non-uniform sprinkler irrigation and plant density on simulated maize yield. Agric. Water Manage. 113, 1-9.

Sammis, T.W., Mapel, C.L., Lugg, D.G., Lansford, R.R., McGuckin, J.T., 1985. Evapotranspiration crop coefficients predicted using growing degree days. Trans. ASAE 28, 773-780.

Sanchez, I., Zapata, N., Faci, J.M., 2010a. Combined effect of technical, meteorological and agronomical factors on solid-set sprinkler irrigation: I. Irrigation performance and soil water recharge in alfalfa and maize. Agric. Water Manage. 97, 1571-1581. 
1 Sanchez, I., Zapata, N., Faci, J.M., 2010b. Combined effect of technical,

2 meteorological and agronomical factors on solid-set sprinkler irrigation: II.

3 Modifications of the wind velocity and of the water interception plane by the

4 crop canopy. Agric. Water Manage. 97, 1591-1601.

5 Seginer, I., Kantz., D., Nir, D., 1991. The distortion by wind of the distribution

6 patterns of single sprinklers. Agric. Water Manage. 19, 341-359.

7 Sharratt, B.S., Sheaffer, C.C., Baker, D.G., 1989. Base temperature for the application of the growing degree day model to field grown alfalfa. Field Crops Res. 21, 95-102.

Sheaffer, C.C., Tanner, C.B., Kirkham, M.B., 1988. Alfalfa water relations and irrigation, in: Hanson, A.A., Barnes, D.K., Hill, R.R. (Eds.), Alfalfa and alfalfa improvement. Agronomy Monograph 29, 373-409. ASA, Madison, WI, USA.

Smeal, D., Gregory, E.J., Arnold, R.N., 1992. Interseasonal variability in the water use-production function of alfalfa. J. Prod. Agric. 5, 576-580.

Stambouli, T., 2012. Gestión avanzada del riego por aspersión en parcela: aplicación en el valle medio del Ebro. Ph. D. Dissertation. Universidad de Zaragoza, Spain. 191 pp.

Stambouli, T., Martínez-Cob, A., Faci, J.M., Howell, T., Zapata, N., 2013. Sprinkler evaporation losses in alfalfa during solid-set sprinkler irrigation in semiarid areas. Irrig. Sci. 31, 1075-1089.

Steiner, J.L., Kanemasu, E.T., Hasza, D., 1983. Microclimatic and crop responses to center pivot sprinkler and to surface irrigation. Irrig. Sci. 4, 201214.

Stern, J., and Bresler, E., 1983. Nonuniform sprinkler irrigation and crop yield. Irrig. Sci. 4, 17-29 
1 Tarjuelo, J.M., Montero, J., Valiente, M., Honrubia, F., Ortiz, J., 1999a. Irrigation

2 uniformity with medium size sprinklers. Part II: Influence of wind and other

3 factors on water distribution. Trans. ASAE 42, 677-689.

4 Tarjuelo, J.M., Montero, J., Honrubia, F.T., Ortiz, J.J., Ortega, J.F., $1999 b$.

5 Analysis of uniformity of sprinkle irrigation in a semi-arid area. Agric. Water

$6 \quad$ Manage. 40, 315-331.

7 Tolk, J.A., Howell, T.A., Steiner, J.L., Krieg, D.R., Schneider, A.D., 1995. Role

8 of transpiration suppression by evaporation of intercepted water in improving

$9 \quad$ irrigation efficiency. Irrig. Sci. 16, 89-95.

10 Urrego-Pereira, Y., Cavero, J., Medina, E.T., Martínez-Cob, A., 2013a.

11 Microclimatic and physiological changes under a center pivot system

12 irrigating maize. Agric. Water Manage. 119, 19-31.

13 Urrego-Pereira, Y., Martínez-Cob, A., Cavero, J., 2013b. Relevance of sprinkler

14 irrigation time and water losses on maize yield. Agron. J. 105, 845-853.

15 Urrego-Pereira, Y., Martínez-Cob, A., Fernández, V., Cavero, J., 2013c.

16 Daytime sprinkler irrigation effects on net photosynthesis of maize and

17 alfalfa. Agron. J. 105, 1515-1528. 
1 Figure 1. General experimental layout, with 12 irrigation sectors (1-12) irrigated

2 independently by four sprinklers each. The irrigation sectors with even numbers

3 were irrigated during nighttime in 2012 , during dayttime in 2013 , and during

4 nighttime in 2014. The irrigation sectors with odd numbers were irrigated during

5 daytime in 2012, during nighttime in 2013, and during daytime in 2014 . The

6 shaded areas are the experimental plots where irrigation events were

7 characterized and alfalfa yield and soil water content were measured. IE,

8 experimental plots where irrigation was characterized. The location of the two

9 access tubes for soil water measurement installed in all the plots is shown in

10 one of them. Two automatic weather stations were located in irrigation sectors 5

11 and 6 in the sprinklers line.

13 Figure 2. Cumulative weekly values of calculated evapotranspiration of the crop

14 (ETC), rainfall, crop irrigation requirement $(\mathrm{CIR})$, and irrigation amount applied to

15 alfalfa for daytime and nighttime irrigation treatments (Irrigation) during the 162012,2013 and 2014 seasons.

18 Figure 3. Soil water content at different depths for the daytime and nighttime

19 irrigation treatments during the experiment. For each date and soil depth, the

20 star symbol indicates statistical difference after ANOVA at $\mathrm{P}=0.05$ (black colour

21 indicates higher value in the nighttime treatment and red colour indicates higher

22 value in the daytime treatment). For each soil layer, the horizontal dashed lines

23 indicate the soil water content at field capacity (upper) and wilting point (lower).

24 The three irrigation seasons $(2012,2013$ and 2014) duration are shown. 
Table 1. Soil characteristics of the experimental field.

\begin{tabular}{|c|c|c|c|c|c|c|c|c|c|}
\hline Depth (m) & $\mathrm{pH}$ & $\mathrm{C}(\%)$ & $\mathrm{N}(\%)$ & $\mathrm{CaCO}_{3}(\%)$ & Sand (\%) & Silt (\%) & Clay (\%) & $\mathrm{FC}^{\mathrm{a}}\left(\mathrm{m}^{3} \mathrm{~m}^{-3}\right)$ & $W P^{b}\left(m^{3} m^{-3}\right)$ \\
\hline $0.0-0.3$ & 8.2 & 1.12 & 0.14 & 35.0 & 19.6 & 50.2 & 30.2 & 0.351 & 0.189 \\
\hline $0.3-0.6$ & 8.3 & 0.77 & 0.11 & 35.0 & 14.9 & 47.5 & 37.6 & 0.381 & 0.227 \\
\hline $0.6-0.9$ & 8.3 & 0.54 & 0.10 & 32.0 & 7.7 & 47.5 & 44.8 & 0.364 & 0.207 \\
\hline $0.9-1.2$ & 8.2 & 0.43 & 0.08 & 31.0 & 11.9 & 47.1 & 41.0 & 0.359 & 0.187 \\
\hline $1.2-1.6$ & 8.3 & 0.43 & 0.07 & 33.0 & 20.3 & 49.2 & 30.5 & 0.344 & 0.187 \\
\hline
\end{tabular}

${ }^{\text {a }}$ FC, field capacity $(-0.033 \mathrm{MPa})$

${ }^{\mathrm{b}} \mathrm{WP}$, wilting point $(-1.5 \mathrm{MPa})$ 
Table 2. Calculated crop evapotranspiration $\left(E T_{C}\right)$, crop irrigation requirement $(C I R)$ and irrigation water applied in the crop seasons of 2012, 2013 and 2014.

\begin{tabular}{llll}
\hline Season & ETc $(\mathrm{mm})$ & CIR $(\mathrm{mm})$ & Irrigation $(\mathrm{mm})$ \\
\hline 2012 & 941 & 746 & 757 \\
2013 & 832 & 556 & 552 \\
2014 & 929 & 711 & 710 \\
\hline
\end{tabular}


Table 3. Average values of wind speed, wind drift and evaporation losses (WDEL), and Christiansen coefficient of uniformity $(\mathrm{CU})$ for the daytime and nighttime irrigations events at each harvest cycle of alfalfa in the three years of the experiment. The average values of wind speed and WDEL for all the irrigation events in each year and the seasonal CU are also given.

\begin{tabular}{|c|c|c|c|c|c|c|c|c|}
\hline \multirow[t]{2}{*}{ Year } & \multirow{2}{*}{$\begin{array}{l}\text { Harvest } \\
\text { cycle }\end{array}$} & \multirow{2}{*}{$\begin{array}{l}\text { Irrigation } \\
\left(\mathrm{N}^{\mathrm{a}}\right)\end{array}$} & \multicolumn{2}{|c|}{ Wind speed $\left(\mathrm{m} \mathrm{s}^{-1}\right)$} & \multicolumn{2}{|c|}{ WDEL (\%) } & \multicolumn{2}{|c|}{ CU (\%) } \\
\hline & & & Daytime & Nighttime & Daytime & Nighttime & Daytime & Nighttime \\
\hline \multirow[t]{8}{*}{2012} & 1 & 4 & 2.98 & 2.30 & 9.74 & 3.99 & 84 & 85 \\
\hline & 2 & 6 & 2.13 & 1.83 & 9.32 & 4.47 & 85 & 88 \\
\hline & 3 & 4 & 1.60 & 1.30 & 6.51 & 3.43 & 89 & 91 \\
\hline & 4 & 6 & 2.15 & 1.70 & 7.55 & 5.60 & 91 & 91 \\
\hline & 5 & 7 & 3.07 & 1.61 & 13.56 & 4.40 & 85 & 87 \\
\hline & 6 & 3 & 2.13 & 1.67 & 6.96 & 0.00 & 85 & 90 \\
\hline & All & 30 & 2.40 & 1.73 & 9.40 & 4.03 & 87 & 88 \\
\hline & Seasonal & & & & & & 94 & 94 \\
\hline \multirow[t]{8}{*}{2013} & 1 & 0 & & & & & & \\
\hline & 2 & 3 & 2.04 & 1.60 & 7.46 & 1.17 & 89 & 86 \\
\hline & 3 & 4 & 1.55 & 1.33 & 5.66 & 0.39 & 91 & 88 \\
\hline & 4 & 6 & 1.66 & 0.72 & 9.75 & 0.95 & 90 & 88 \\
\hline & 5 & 7 & 2.68 & 1.57 & 13.39 & 1.55 & 87 & 88 \\
\hline & 6 & 6 & 2.95 & 1.56 & 14.70 & 1.86 & 82 & 83 \\
\hline & All & 26 & 2.26 & 1.34 & 10.97 & 1.26 & 87 & 87 \\
\hline & Seasonal & & & & & & 92 & 92 \\
\hline \multirow[t]{8}{*}{2014} & 1 & 2 & 1.70 & 1.05 & 6.23 & 1.19 & 87 & 93 \\
\hline & 2 & 6 & 2.21 & 2.00 & 7.22 & 5.08 & 88 & 88 \\
\hline & 3 & 4 & 2.13 & 0.86 & 7.05 & 2.14 & 89 & 91 \\
\hline & 4 & 7 & 4.40 & 1.88 & 19.60 & 6.49 & 76 & 88 \\
\hline & 5 & 7 & 2.39 & 1.45 & 8.86 & 2.90 & 85 & 90 \\
\hline & 6 & 4 & 1.59 & 0.80 & 3.02 & 3.30 & 91 & 90 \\
\hline & All & 30 & 2.63 & 1.45 & 9.84 & 3.92 & 85 & 89 \\
\hline & Seasonal & & & & & & 92 & 94 \\
\hline
\end{tabular}

\footnotetext{
${ }^{a}$ Number of irrigation events
} 
Table 4. Average air temperature and vapor pressure deficit (VPD) measured above the crop canopy at 1 and $2 \mathrm{~m}$ above the soil surface and canopy temperature of alfalfa in the irrigated (Irrig) and not irrigated (Not irrig) plots during and after the daytime irrigation events for each year. The irrigation events considered were those when thermal time was more than a third of total for each alfalfa harvest cycle.

\begin{tabular}{|c|c|c|c|c|c|c|c|}
\hline \multirow[t]{2}{*}{ Variable and year } & \multirow[b]{2}{*}{$N^{a}$} & \multicolumn{2}{|c|}{ During irrigation } & \multicolumn{2}{|c|}{$1 \mathrm{~h}$ after irrigation } & \multicolumn{2}{|c|}{$2 \mathrm{~h}$ after irrigation } \\
\hline & & Irrig & Not irrig & Irrig & Not irrig & Irrig & Not irrig \\
\hline \multicolumn{8}{|l|}{ Air temperature $\left({ }^{\circ} \mathrm{C}\right)$ at $1 \mathrm{~m}$} \\
\hline 2012 & 18 & $26.0 b^{b}$ & $27.3 \mathrm{a}$ & $28.9 \mathrm{~b}$ & $29.7 \mathrm{a}$ & $29.5 b$ & $29.8 \mathrm{a}$ \\
\hline 2013 & 18 & $23.6 \mathrm{~b}$ & $24.5 \mathrm{a}$ & $26.5 \mathrm{~b}$ & $26.8 \mathrm{a}$ & $27.1 \mathrm{a}$ & $27.0 \mathrm{a}$ \\
\hline 2014 & 24 & $22.5 \mathrm{~b}$ & $23.4 \mathrm{a}$ & $25.4 \mathrm{~b}$ & $26.1 \mathrm{a}$ & $26.1 \mathrm{a}$ & $26.1 \mathrm{a}$ \\
\hline \multicolumn{8}{|l|}{ Air temperature $\left({ }^{\circ} \mathrm{C}\right)$ at $2 \mathrm{~m}$} \\
\hline 2012 & 22 & $24.4 \mathrm{~b}$ & $25.1 \mathrm{a}$ & $27.8 \mathrm{a}$ & $27.9 \mathrm{a}$ & $28.3 \mathrm{a}$ & $28.2 \mathrm{a}$ \\
\hline 2013 & 18 & $23.2 b$ & $24.5 \mathrm{a}$ & $26.4 \mathrm{~b}$ & $27.2 \mathrm{a}$ & $27.2 b$ & $27.5 \mathrm{a}$ \\
\hline 2014 & 24 & $22.6 \mathrm{~b}$ & $23.0 \mathrm{a}$ & $25.9 \mathrm{a}$ & $25.9 \mathrm{a}$ & $26.5 \mathrm{a}$ & $26.1 \mathrm{~b}$ \\
\hline \multicolumn{8}{|l|}{ VPD $(\mathrm{kPa})$ at $1 \mathrm{~m}$} \\
\hline 2012 & 18 & $1.65 b$ & $1.98 \mathrm{a}$ & $2.42 \mathrm{~b}$ & $2.61 \mathrm{a}$ & $2.66 \mathrm{a}$ & $2.73 \mathrm{a}$ \\
\hline 2013 & 18 & $1.17 \mathrm{~b}$ & $1.36 \mathrm{a}$ & $1.85 \mathrm{a}$ & $1.87 \mathrm{a}$ & $2.04 \mathrm{a}$ & $1.99 \mathrm{a}$ \\
\hline 2014 & 24 & $1.10 \mathrm{~b}$ & $1.39 \mathrm{a}$ & $1.75 \mathrm{~b}$ & $1.96 \mathrm{a}$ & $1.95 b$ & $2.02 \mathrm{a}$ \\
\hline \multicolumn{8}{|l|}{ VPD $(\mathrm{kPa})$ at $2 \mathrm{~m}$} \\
\hline 2012 & 22 & $1.63 \mathrm{~b}$ & $1.95 \mathrm{a}$ & $2.52 \mathrm{~b}$ & $2.66 \mathrm{a}$ & $2.71 \mathrm{a}$ & $2.76 \mathrm{a}$ \\
\hline 2013 & 18 & $1.23 \mathrm{~b}$ & $1.46 \mathrm{a}$ & $2.00 \mathrm{~b}$ & $2.10 \mathrm{a}$ & $2.25 \mathrm{a}$ & $2.23 \mathrm{a}$ \\
\hline 2014 & 24 & $1.24 \mathrm{~b}$ & $1.43 \mathrm{a}$ & $2.00 \mathrm{~b}$ & $2.08 \mathrm{a}$ & $2.16 \mathrm{a}$ & $2.16 \mathrm{a}$ \\
\hline \multicolumn{8}{|l|}{ Canopy temperature $\left({ }^{\circ} \mathrm{C}\right)$} \\
\hline 2012 & 22 & $23.3 \mathrm{~b}$ & $24.2 \mathrm{a}$ & $23.8 \mathrm{a}$ & $24.2 \mathrm{a}$ & $23.2 \mathrm{a}$ & $23.3 \mathrm{a}$ \\
\hline 2013 & 18 & $23.3 \mathrm{~b}$ & $24.0 \mathrm{a}$ & $24.8 \mathrm{a}$ & $24.7 \mathrm{a}$ & $24.4 \mathrm{a}$ & $24.3 \mathrm{a}$ \\
\hline 2014 & 24 & $21.9 \mathrm{~b}$ & $23.9 \mathrm{a}$ & $23.8 \mathrm{~b}$ & $24.6 \mathrm{a}$ & $23.7 \mathrm{a}$ & $23.9 \mathrm{a}$ \\
\hline
\end{tabular}

${ }^{a}$ Number of irrigation events.

${ }^{b}$ For each variable, year and period of measurement the values followed by different letters are significantly different according to a paired $t$-test at the 0.05 level. 
Table 5. Average air temperature and vapor pressure deficit (VPD) measured above the crop canopy at 1 and $2 \mathrm{~m}$ above the soil surface and canopy temperature of alfalfa in the irrigated (Irrig) and not irrigated (Not irrig) plots during and after the nighttime irrigation events for each year. The irrigation events considered were those when thermal time was more than a third of total for each alfalfa harvest.

\begin{tabular}{|c|c|c|c|c|c|c|c|}
\hline \multirow[t]{2}{*}{ Variable and year } & \multirow[b]{2}{*}{$\mathrm{N}^{\mathrm{a}}$} & \multicolumn{2}{|c|}{ During irrigation } & \multicolumn{2}{|c|}{$1 \mathrm{~h}$ after irrigation } & \multicolumn{2}{|c|}{$2 \mathrm{~h}$ after irrigation } \\
\hline & & Irrig & Not irrig & Irrig & Not irrig & Irrig & Not irrig \\
\hline \multicolumn{8}{|c|}{ Air temperature $\left({ }^{\circ} \mathrm{C}\right)$ at $1 \mathrm{~m}$} \\
\hline 2012 & 18 & $17.0 b^{b}$ & $17.5 \mathrm{a}$ & $15.4 \mathrm{~b}$ & $15.8 \mathrm{a}$ & $16.7 \mathrm{a}$ & $16.9 \mathrm{a}$ \\
\hline 2013 & 19 & $15.6 \mathrm{a}$ & $15.5 \mathrm{a}$ & $14.9 \mathrm{a}$ & $14.8 \mathrm{a}$ & $15.6 \mathrm{a}$ & $15.5 \mathrm{a}$ \\
\hline 2014 & 22 & $14.0 \mathrm{~b}$ & $14.7 \mathrm{a}$ & $13.2 b$ & $13.8 \mathrm{a}$ & $13.8 \mathrm{~b}$ & $14.4 \mathrm{a}$ \\
\hline \multicolumn{8}{|c|}{ Air temperature $\left({ }^{\circ} \mathrm{C}\right)$ at $2 \mathrm{~m}$} \\
\hline 2012 & 22 & $15.8 \mathrm{~b}$ & $16.6 \mathrm{a}$ & $14.4 \mathrm{~b}$ & $15.0 \mathrm{a}$ & $15.2 b$ & $15.7 \mathrm{a}$ \\
\hline 2013 & 19 & $16.2 \mathrm{a}$ & $16.1 \mathrm{a}$ & $15.4 \mathrm{a}$ & $15.3 \mathrm{a}$ & $15.8 \mathrm{a}$ & $15.7 \mathrm{a}$ \\
\hline 2014 & 22 & $14.5 b$ & $15.4 \mathrm{a}$ & $13.5 b$ & $14.3 \mathrm{a}$ & $14.1 \mathrm{~b}$ & $14.8 \mathrm{a}$ \\
\hline \multicolumn{8}{|l|}{ VPD $(\mathrm{kPa})$ at $1 \mathrm{~m}$} \\
\hline 2012 & 18 & $0.39 \mathrm{~b}$ & $0.49 \mathrm{a}$ & $0.25 b$ & $0.32 \mathrm{a}$ & $0.35 b$ & $0.39 \mathrm{a}$ \\
\hline 2013 & 19 & $0.24 \mathrm{~b}$ & $0.28 \mathrm{a}$ & $0.18 b$ & $0.21 \mathrm{a}$ & $0.20 \mathrm{~b}$ & $0.24 \mathrm{a}$ \\
\hline 2014 & 22 & $0.24 b$ & $0.30 \mathrm{a}$ & $0.19 \mathrm{~b}$ & $0.24 \mathrm{a}$ & $0.22 b$ & $0.28 \mathrm{a}$ \\
\hline \multicolumn{8}{|l|}{ VPD $(\mathrm{kPa})$ at $2 \mathrm{~m}$} \\
\hline 2012 & 22 & $0.44 \mathrm{~b}$ & $0.51 \mathrm{a}$ & $0.31 \mathrm{~b}$ & $0.34 \mathrm{a}$ & $0.37 \mathrm{a}$ & $0.38 \mathrm{a}$ \\
\hline 2013 & 19 & $0.28 \mathrm{~b}$ & $0.34 \mathrm{a}$ & $0.21 b$ & $0.26 \mathrm{a}$ & $0.22 b$ & $0.27 \mathrm{a}$ \\
\hline 2014 & 22 & $0.25 b$ & $0.36 \mathrm{a}$ & $0.20 \mathrm{~b}$ & $0.28 \mathrm{a}$ & $0.24 \mathrm{~b}$ & $0.31 \mathrm{a}$ \\
\hline \multicolumn{8}{|l|}{ Canopy temperature $\left({ }^{\circ} \mathrm{C}\right)$} \\
\hline 2012 & 22 & $13.6 \mathrm{a}$ & $13.8 \mathrm{a}$ & $12.3 b$ & $12.6 \mathrm{a}$ & $13.7 \mathrm{~b}$ & $14.0 \mathrm{a}$ \\
\hline 2013 & 19 & $14.2 \mathrm{a}$ & $14.4 \mathrm{a}$ & $13.6 \mathrm{~b}$ & $14.0 \mathrm{a}$ & $14.8 b$ & $15.0 \mathrm{a}$ \\
\hline 2014 & 22 & $12.8 \mathrm{~b}$ & $13.0 \mathrm{a}$ & $12.1 \mathrm{~b}$ & $12.5 \mathrm{a}$ & $13.2 \mathrm{~b}$ & $13.5 \mathrm{a}$ \\
\hline
\end{tabular}

${ }^{a}$ Number of irrigation events.

${ }^{b}$ For each variable, year and period of measurement the values followed by different letters are significantly different according to a paired $t$-test at the 0.05 level. 
Table 6. Average values of daily crop water stress index in the daytime and nighttime irrigation treatments at each alfalfa harvest cycle of the three years of the experiment.

\begin{tabular}{lrrrrrr}
\hline Harvest & \multicolumn{5}{c}{ Crop water stress index } \\
\cline { 2 - 7 } cycle & \multicolumn{2}{c}{2012} & \multicolumn{5}{c}{2013} & \multicolumn{2}{c}{2014} \\
\cline { 2 - 7 } & Daytime & Nighttime & Daytime & Nighttime & Daytime & Nighttime \\
\hline 1 & $0.51 \mathrm{~b}^{\mathrm{a}}$ & $0.55 \mathrm{a}$ & $0.62 \mathrm{a}$ & $0.47 \mathrm{~b}$ & $0.53 \mathrm{~b}$ & $0.60 \mathrm{a}$ \\
2 & $0.20 \mathrm{a}$ & $0.28 \mathrm{a}$ & $0.47 \mathrm{a}$ & $0.32 \mathrm{~b}$ & $0.43 \mathrm{a}$ & $0.36 \mathrm{a}$ \\
3 & $0.20 \mathrm{a}$ & $0.18 \mathrm{a}$ & $0.47 \mathrm{a}$ & $0.27 \mathrm{~b}$ & $0.39 \mathrm{a}$ & $0.39 \mathrm{a}$ \\
4 & $0.17 \mathrm{a}$ & $0.18 \mathrm{a}$ & $0.25 \mathrm{a}$ & $0.13 \mathrm{~b}$ & $0.30 \mathrm{a}$ & $0.26 \mathrm{a}$ \\
5 & $0.07 \mathrm{~b}$ & $0.15 \mathrm{a}$ & $0.26 \mathrm{a}$ & $0.14 \mathrm{~b}$ & $0.20 \mathrm{a}$ & $0.25 \mathrm{a}$ \\
6 & $0.12 \mathrm{~b}$ & $0.17 \mathrm{a}$ & $0.21 \mathrm{a}$ & $0.07 \mathrm{a}$ & $0.18 \mathrm{a}$ & $0.19 \mathrm{a}$ \\
\hline
\end{tabular}

${ }^{\mathrm{a}}$ For each year and harvest the values followed by different letters are significantly

different according to a paired $t$-test at the 0.05 level. 
Table 7. Alfalfa forage yield (dry matter) in the daytime and nighttime irrigation treatments at each harvest cycle of the three years of the experiment.

\begin{tabular}{lrrrrrr}
\hline \multirow{2}{*}{$\begin{array}{l}\text { Harvest } \\
\text { cycle }\end{array}$} & \multicolumn{6}{c}{ Forage yield $\left(\mathrm{Mg} \mathrm{ha}^{-1}\right)$} \\
\cline { 2 - 7 } & Daytime & Nighttime & Daytime & Nighttime & Daytime & Nighttime \\
\hline 1 & $3.02 \mathrm{a}^{\mathrm{a}}$ & $2.83 \mathrm{a}$ & $3.59 \mathrm{a}$ & $3.48 \mathrm{a}$ & $3.12 \mathrm{a}$ & $3.19 \mathrm{a}$ \\
2 & $3.26 \mathrm{a}$ & $3.48 \mathrm{a}$ & $4.05 \mathrm{a}$ & $4.05 \mathrm{a}$ & $4.26 \mathrm{a}$ & $3.92 \mathrm{a}$ \\
3 & $3.10 \mathrm{a}$ & $3.07 \mathrm{a}$ & $3.85 \mathrm{a}$ & $3.89 \mathrm{a}$ & $3.85 \mathrm{a}$ & $4.09 \mathrm{a}$ \\
4 & $3.13 \mathrm{a}$ & $2.93 \mathrm{a}$ & $4.02 \mathrm{a}$ & $4.02 \mathrm{a}$ & $3.97 \mathrm{~b}$ & $4.41 \mathrm{a}$ \\
5 & $2.50 \mathrm{a}$ & $2.60 \mathrm{a}$ & $2.87 \mathrm{a}$ & $3.10 \mathrm{a}$ & $4.09 \mathrm{a}$ & $4.02 \mathrm{a}$ \\
6 & $1.00 \mathrm{a}$ & $1.11 \mathrm{a}$ & $2.11 \mathrm{a}$ & $2.25 \mathrm{a}$ & $2.34 \mathrm{a}$ & $2.35 \mathrm{a}$ \\
All & $16.02 \mathrm{a}$ & $16.02 \mathrm{a}$ & $20.48 \mathrm{a}$ & $20.79 \mathrm{a}$ & $21.64 \mathrm{a}$ & $22.00 \mathrm{a}$ \\
\hline
\end{tabular}

${ }^{a}$ For each year and harvest cycle the numbers with different letters are significantly different after ANOVA at the $\mathrm{P}=0.05$ level. 
Table 8. Alfalfa forage $\mathrm{N}$ content (yield weighted) and $\mathrm{N}$ uptake in the daytime (Day) and nighttime (Night) irrigation treatments at each harvest of the three years of the experiment.

\begin{tabular}{|c|c|c|c|c|c|c|c|c|c|c|c|c|}
\hline \multirow[t]{3}{*}{ Harvest } & \multicolumn{6}{|c|}{$\mathrm{N}$ content $(\%)$} & \multicolumn{6}{|c|}{ N uptake $\left(\mathrm{kg} \mathrm{ha}^{-1}\right)$} \\
\hline & \multicolumn{2}{|c|}{2012} & \multicolumn{2}{|c|}{2013} & \multicolumn{2}{|c|}{2014} & \multicolumn{2}{|c|}{2012} & \multicolumn{2}{|c|}{2013} & \multicolumn{2}{|c|}{2014} \\
\hline & Day & Night & Day & Night & Day & Night & Day & Night & Day & Night & Day & Night \\
\hline 1 & $3.49 \mathrm{a}^{\mathrm{a}}$ & $3.48 \mathrm{a}$ & $3.48 \mathrm{a}$ & $3.48 \mathrm{a}$ & $3.39 \mathrm{a}$ & $3.44 \mathrm{a}$ & $105 \mathrm{a}$ & $99 a$ & $125 a$ & $121 \mathrm{a}$ & $106 a$ & $110 \mathrm{a}$ \\
\hline 2 & $3.47 \mathrm{a}$ & $3.46 \mathrm{a}$ & $2.98 \mathrm{a}$ & $2.84 \mathrm{a}$ & $3.31 \mathrm{a}$ & $3.31 \mathrm{a}$ & $113 a$ & $120 \mathrm{a}$ & $120 \mathrm{a}$ & $115 a$ & $140 \mathrm{a}$ & $130 \mathrm{a}$ \\
\hline 3 & $3.30 \mathrm{a}$ & $3.19 \mathrm{a}$ & $3.20 \mathrm{a}$ & $3.20 \mathrm{a}$ & $3.45 \mathrm{a}$ & $3.46 \mathrm{a}$ & $102 a$ & $98 a$ & $123 a$ & $124 a$ & $132 \mathrm{a}$ & $141 \mathrm{a}$ \\
\hline 4 & $3.22 \mathrm{a}$ & $3.13 \mathrm{a}$ & $3.10 \mathrm{a}$ & $3.06 \mathrm{a}$ & $3.31 \mathrm{a}$ & $3.17 b$ & $101 \mathrm{a}$ & $92 \mathrm{~b}$ & $125 \mathrm{a}$ & $123 a$ & $131 \mathrm{a}$ & $140 \mathrm{a}$ \\
\hline 5 & $3.06 \mathrm{a}$ & $3.00 \mathrm{a}$ & $3.10 \mathrm{a}$ & $3.10 \mathrm{a}$ & $3.34 \mathrm{a}$ & $3.42 \mathrm{a}$ & $76 \mathrm{a}$ & $78 \mathrm{a}$ & $88 \mathrm{a}$ & $95 \mathrm{a}$ & $136 \mathrm{a}$ & $138 \mathrm{a}$ \\
\hline 6 & $2.67 \mathrm{a}$ & $2.53 \mathrm{a}$ & $3.60 \mathrm{a}$ & $3.43 \mathrm{a}$ & $3.58 \mathrm{a}$ & $3.47 \mathrm{a}$ & $27 \mathrm{a}$ & $28 \mathrm{a}$ & $76 \mathrm{a}$ & $77 \mathrm{a}$ & $84 \mathrm{a}$ & $82 \mathrm{a}$ \\
\hline All & $3.28 \mathrm{a}$ & $3.21 \mathrm{a}$ & $3.21 \mathrm{a}$ & $3.16 \mathrm{a}$ & $3.38 \mathrm{a}$ & $3.37 \mathrm{a}$ & $524 \mathrm{a}$ & $514 \mathrm{a}$ & $657 \mathrm{a}$ & $655 a$ & $729 \mathrm{a}$ & $740 \mathrm{a}$ \\
\hline
\end{tabular}

${ }^{\mathrm{a}}$ For each variable, year and harvest the numbers with different letters are significantly different after ANOVA at the $\mathrm{P}=0.05$ level. 
Table 9. Seasonal alfalfa actual evapotranspiration (calculated with a water balance) and water use efficiency in the daytime and nighttime irrigation treatments of the three years of the experiment.

\begin{tabular}{|c|c|c|c|c|c|c|}
\hline \multirow[t]{2}{*}{ Variable } & \multicolumn{2}{|c|}{2012} & \multicolumn{2}{|c|}{2013} & \multicolumn{2}{|c|}{2014} \\
\hline & Daytime & Nighttime & Daytime & Nighttime & Daytime & Nighttime \\
\hline Evapotranspiration (mm) & $878 a^{a}$ & $867 \mathrm{a}$ & $832 \mathrm{a}$ & 802 b & $891 \mathrm{a}$ & $885 a$ \\
\hline Water use efficiency $\left(\mathrm{kg} \mathrm{ha}^{-1} \mathrm{~mm}^{-1}\right)$ & $17.71 \mathrm{a}$ & $18.59 \mathrm{a}$ & $24.62 \mathrm{a}$ & $25.94 \mathrm{a}$ & $24.28 \mathrm{a}$ & $24.85 a$ \\
\hline
\end{tabular}




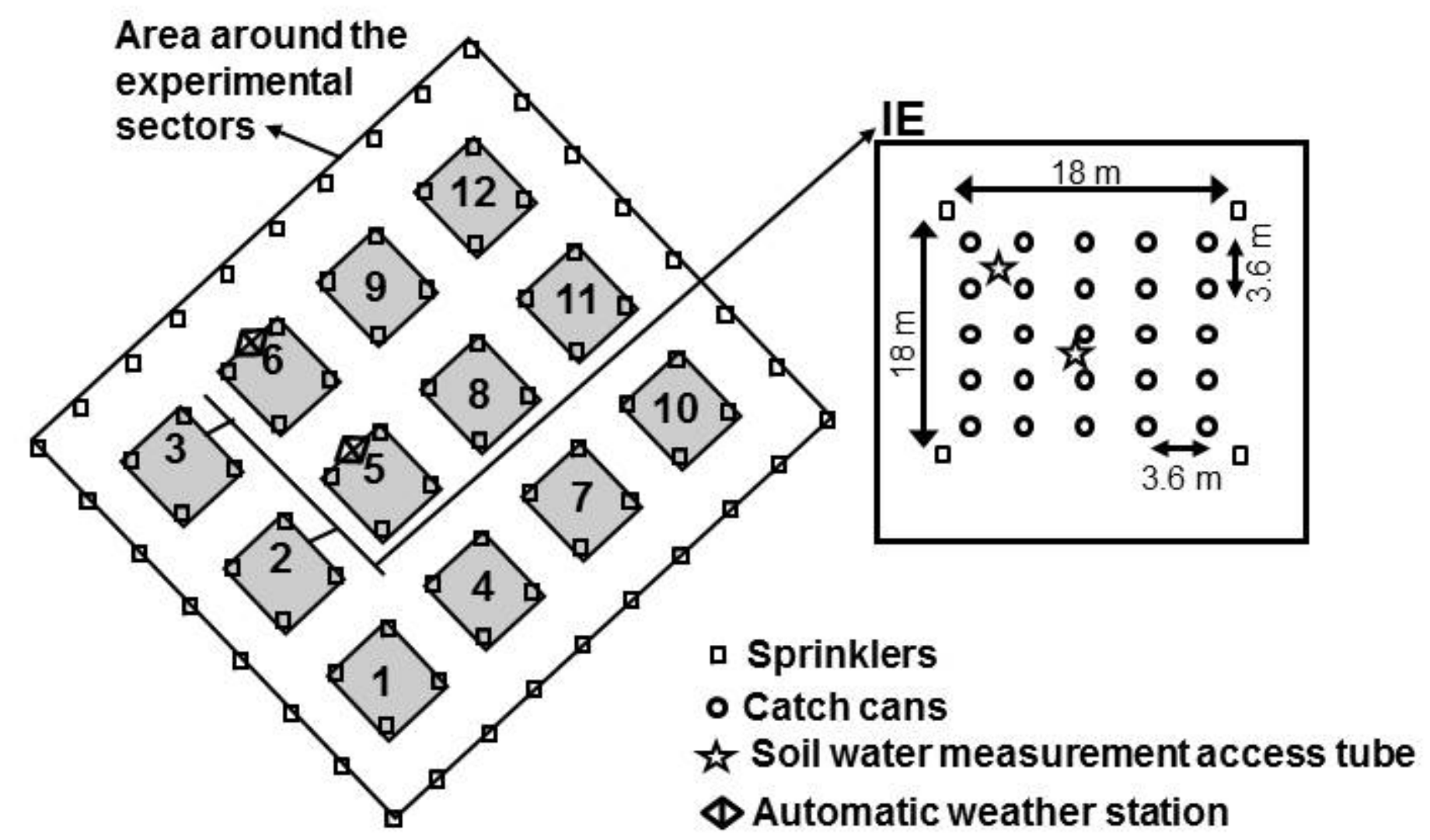




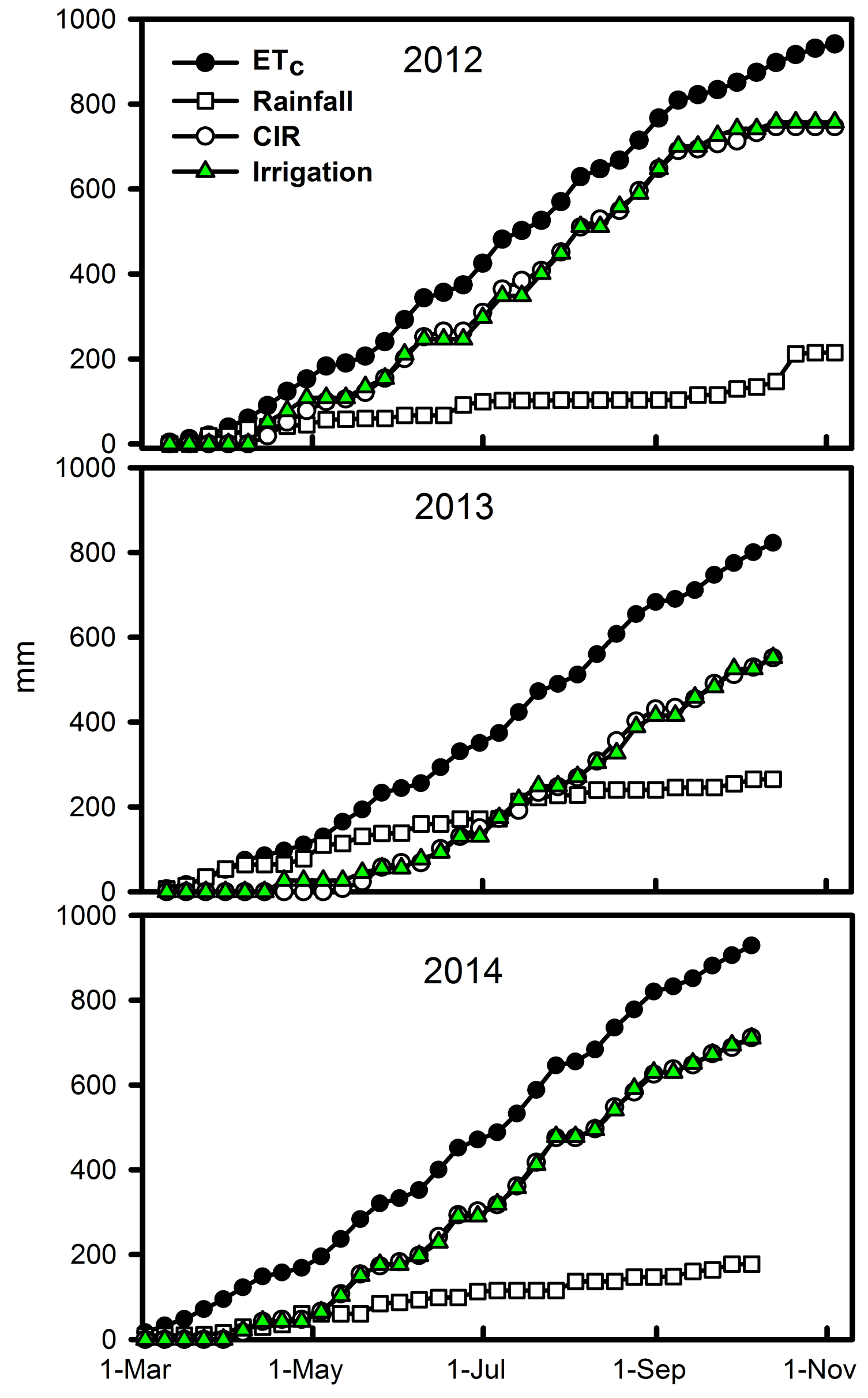




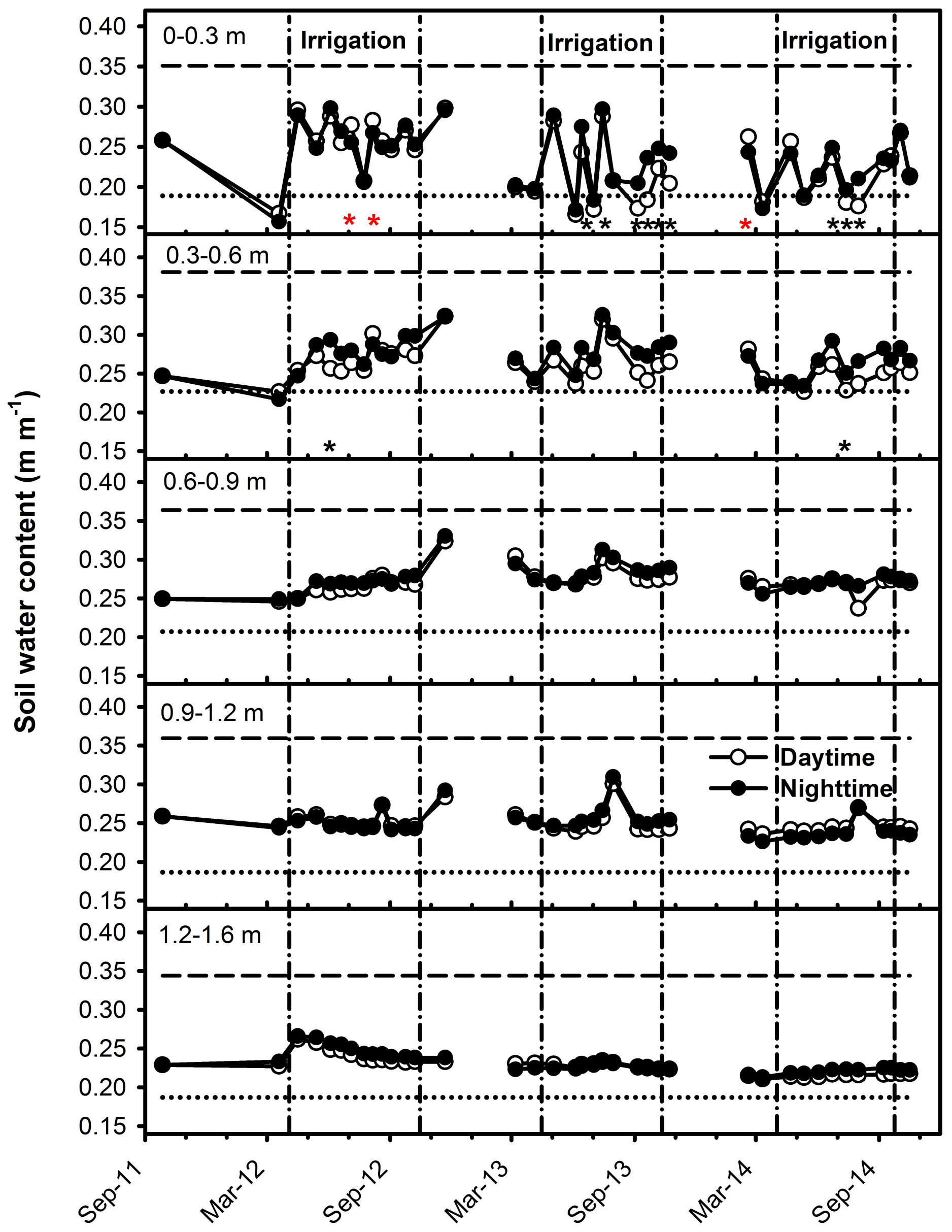

